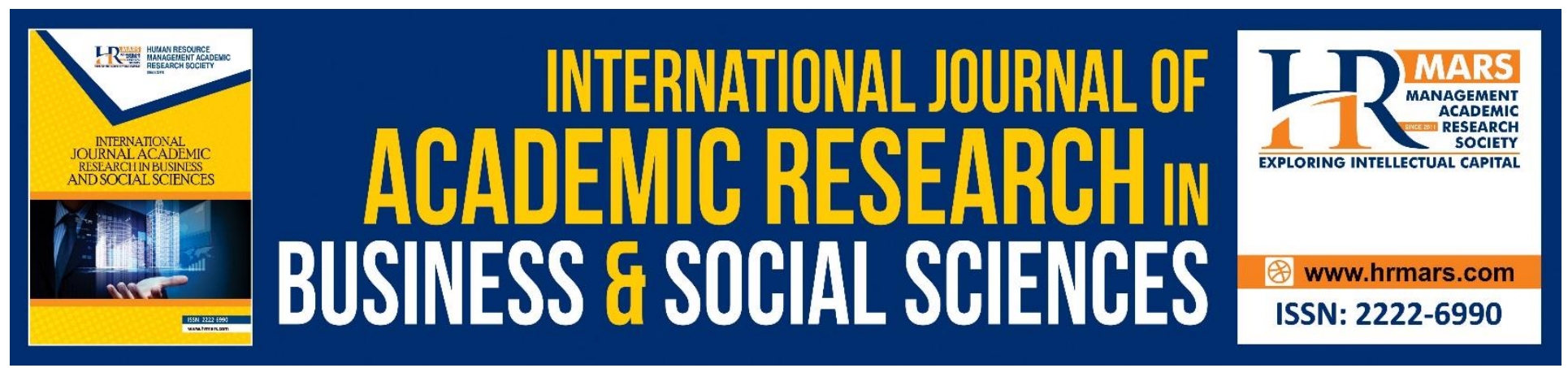

\title{
Exploring Local Food Characteristics in Developing Food Tourism Destination at Lenggong Valley, Perak
}

\author{
Mohd Nazri Abdul Raji, Shahrim Ab. Karim, Farah Adibah Che Ishak, Mohd \\ Mursyid Arshad
}

To Link this Article: http://dx.doi.org/10.6007/IJARBSS/v10-i6/7462

DOI:10.6007/IJARBSS/v10-i6/7462

Received: 07 April 2020, Revised: 11 May 2020, Accepted: 04 June 2020

Published Online: 09 July 2020

In-Text Citation: (Raji et al., 2020)

To Cite this Article: Raji, M. N. A., Karim, S. A., Ishak, F. A. C., \& Arshad, M. M. (2020). Exploring Local Food Characteristics in Developing Food Tourism Destination at Lenggong Valley, Perak. International Journal of Academic Research in Business and Social Sciences, 10(6), 927-936.

Copyright: (C) 2020 The Author(s)

Published by Human Resource Management Academic Research Society (www.hrmars.com)

This article is published under the Creative Commons Attribution (CC BY 4.0) license. Anyone may reproduce, distribute, translate and create derivative works of this article (for both commercial and non-commercial purposes), subject to full attribution to the original publication and authors. The full terms of this license may be seen at: http://creativecommons.org/licences/by/4.0/legalcode

Vol. 10, No. 6, 2020, Pg. 927 - 936

http://hrmars.com/index.php/pages/detail/IJARBSS

JOURNAL HOMEPAGE

Full Terms \& Conditions of access and use can be found at http://hrmars.com/index.php/pages/detail/publication-ethics 


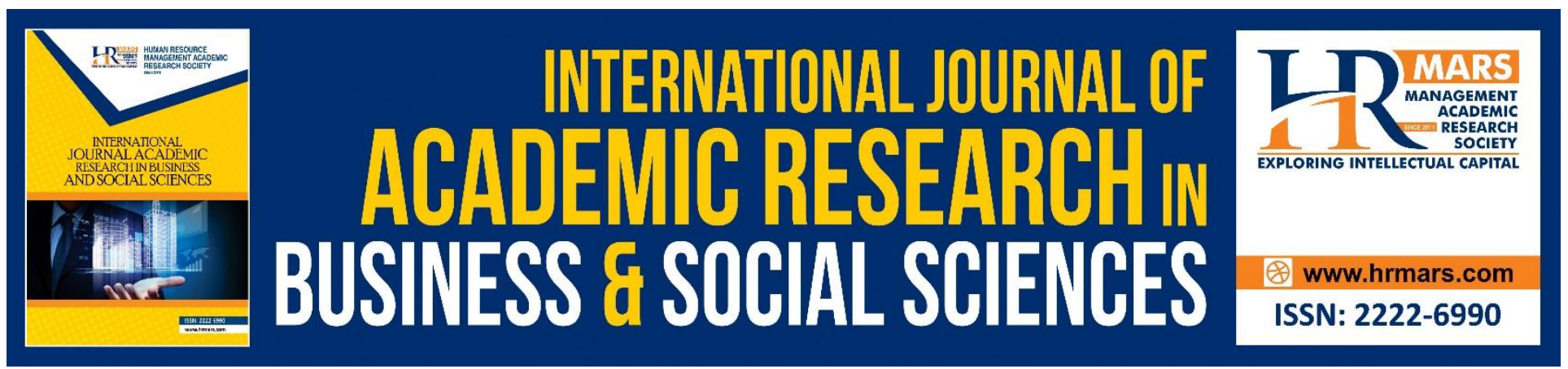

\title{
Exploring Local Food Characteristics in Developing Food Tourism Destination at Lenggong Valley, Perak
}

\author{
Mohd Nazri Abdul Raji1, Shahrim Ab. Karim², Farah Adibah Che \\ Ishak $^{3}$, Mohd Mursyid Arshad 4 \\ 1,2,3 Department of Food Service and Management, Faculty of Food Science and Technology, \\ Universiti Putra Malaysia, 43400 UPM Serdang, Selangor, Malaysia, ${ }^{4}$ Department of Professional \\ Development and Continuing Education, Faculty of Food Educational Studies, Universiti Putra \\ Malaysia, 43400 UPM Serdang, Selangor, Malaysia
}

\begin{abstract}
Many tourist destinations have started to recognize their local food as the core element or supporting attraction of their intangible heritage. Thus, integration of the relationship between food and tourism destination has become an important issue in the current food tourism study which covers various aspects. This study aims to explore the local food characteristics in Lenggong Valley, Perak. Data were collected through in-depth, semi-structured interviews and supported with participant observation. A total of nine informants were involved in this study comprising of traditional local food experts, local food providers, and local authorities. Four main characteristics of Lenggong local food were identified. These include i) practicing food culture using natural ingredients, ii) Malay traditional food as main dishes iii) the use of wild edible plants in traditional cooking and iv) freshwater fish sources used as signature dishes. The findings showed that Lenggong Valley is rich with assorted natural resources and diverse food cultural backgrounds that could be highlighted as a potential attraction to develop more memorable tourism experiences. It can also assist public and private agencies to develop food tourism at a destination by incorporating local food through tourism marketing strategies, in a way of destination's culinary culture representation. Keywords: Local Food, Tourism Destination, Food Tourism, Lenggong Valley, Local Food Characteristics.
\end{abstract}

\section{Introduction}

Lenggong Valley (Figure 1) is a rural tourist destination in Peninsular Malaysia located in the Hulu Perak District of the Perak state. It is situated $62 \mathrm{~km}$ from the town of Kuala Kangsar and $75 \mathrm{~km}$ north of Ipoh. Lenggong Valley comprises of an area of 9,590 hectares out of 21,013 hectares of the Perak area. The total population is approximately about 17,000 people (Lenggong District Council, 2020). The majority of the population is of the Malay ethnicity follow by Chinese, Indian and indigenous peoples. Today, Lenggong Valley is not only surrounded by the natural green area with flora and fauna, but is also known as one of the important heritage tourist attractions in Malaysia. 


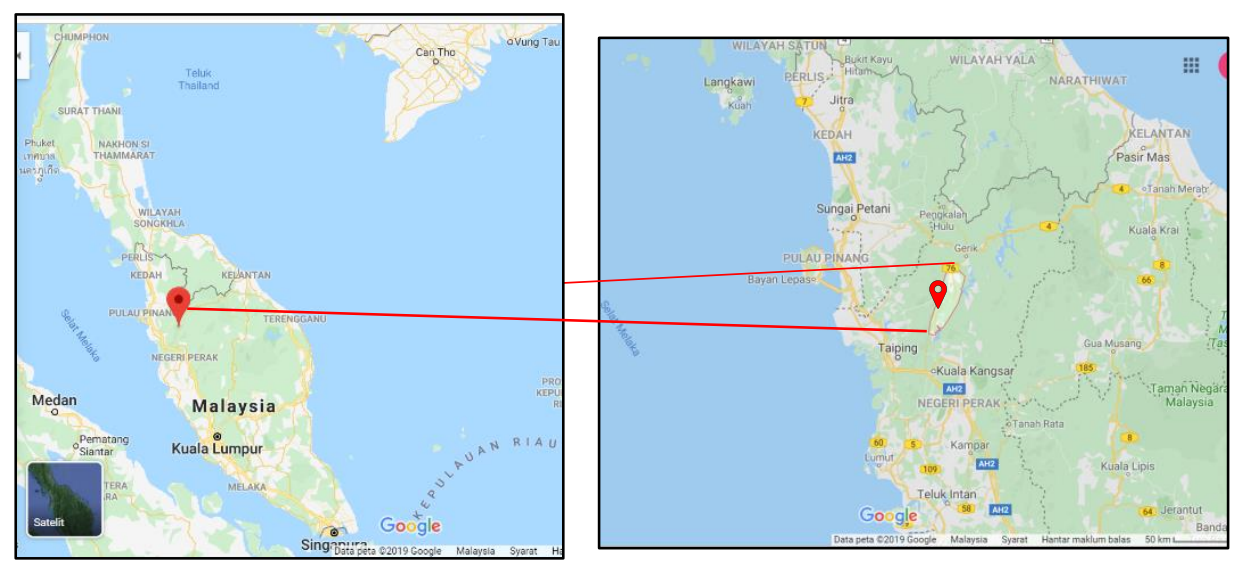

Figure 1. The location of Lenggong Valley (Google maps)

Lenggong Valley was awarded as a World Heritage Site (WHS) on $30^{\text {th }}$ June 2012 by United Nations Educational, Scientific and Cultural Organization (UNESCO) due to its prehistorical human settlement from the Palaeolithic, Neolithic and Metal ages (Kwong \& Mohamed, 2017). This site was a centre for the longest development of human civilization (Hassan, Zakaria, Hamid, Rindam, \& Yahya, 2013). Lenggong Valley is like an open-air museum and is home to legends, skeletons, a cave and workshop sites with previous finds such as weapons, pottery and stone tools (Kwong \& Mohamed, 2017). However, being recognized as WHS is not merely a typical status but it comes with the task to maintain the award given. Furthermore, this award will be more meaningful if Lenggong Valley is able to compete with other tourist destinations in the global market.

Since tourism destinations are competing for tourists in the global market, they need to continuously identify and emphasize characteristics that make them distinguishable. Thus, presenting a strong identity and positive image are critically important for every tourist destination to sustain in this industry. In this regard, Lenggong Valley is no exception and it needs further improvement to increase its competitive advantages in the tourism market (Hassan et al., 2013). Apart from being a famous archaeological attraction, Lenggong Valley is also rich with non-archaeological resources such as local food. A recent study that explored the uniqueness of Lenggong Valley mentioned its local food as an important tourism element to support the image and identity of Lenggong Valley as a rural tourist destination (Shobri \& Hassan, 2017). However, little empirical research has been conducted to determine the characteristics of local food before integrating it with the tourism destination. As Horng and Tsai (2012) asserted, the destination should examine the tourism resource at hand before developing marketing strategies. Therefore, this study aims to explore the characteristics of local food to increase the attraction and develop competitive advantages for Lenggong Valley.

\section{Literature Review Local Food}

Kim, Eves and Scarles (2009) defined local food as a product that is locally processed and has a local identity, including being locally produced and regionally branded. Local food also refers to a product that reveals the culture and culinary tradition of a local community (Bessière, 1998). In other words, 
local food expresses regional and national identity and can enhance the image of a tourist destination (Bessière, 1998). Furthermore, local food at a tourist destination may have a major significant implication for the economy and cultural and environment sustainability. Many studies argue that locally sourced local food can result in benefits for both the host and visitors (Bessière, 1998; Choe \& Kim, 2018). As such, local food at tourist destinations is an important invisible heritage product that can potentially be used to develop food tourism in many regions, states or countries.

\section{Food Tourism}

Food does not only fulfill the physical need for humans, but also plays an important role in the tourism sector as tourists need to eat whenever they travel (Kim \& Iwashita, 2015). In the tourism context, however, food is more than just eating hunger. It delivers the meaning through human sense such as sight, sound, smell, taste and touch. Previous studies have provided evidence on the benefit of integrating food and tourism in various perspectives. For example, food is essential element that can help to create a sense of place (Haven-Tang \& Jones, 2005), add authenticity of the tourist destination (Sims, 2009), it can act as the supporting or main motivator to the traveller (Ellis, Park, \& Sangkyun, 2018) and boost the local economy development (Choe \& Kim, 2018; Lunchaprasith, 2017). Therefore, food tourism strategies play essential role in destination marketing and can be used as a promotional tool to enhance a destination's competitive advantages (du Rand, Heath, \& Alberts, 2003). This strategy is vital to tourist destinations but not strategically emphasized by many destinations, especially the rural areas.

\section{Methodology}

A qualitative method was used to explore the local food characteristics in Lenggong Valley, Perak. This type of methodology is appropriate to be used in this study because it focuses on exploratory and in-depth understanding regarding the knowledge of Lenggong local food. As Creswell (2013) asserted, a qualitative research is designed to clarify an unclear phenomenon and build an in-depth understanding about a particular phenomenon. Since there are limited studies that explain the characteristics of Lenggong local food, a qualitative approach was deemed as the best method to be employed in this study. Purposive sampling technique was used in this study which involved nine informants comprising of traditional local food experts, local food providers, and local authorities. Silverman (2013) emphasizes that the purposive sampling technique involves selecting the informant based on a specific purpose rather than randomly. Moreover, to reach saturation point in this study, the snowball sampling technique was employed by the researcher to recruit more informants. According to Lebar (2007), the snowball technique in qualitative research provides more space for the researcher to identify the best individuals to be the informants. Furthermore, Jennings (2001) argued that the snowball sampling technique is used when it is difficult to reach participants.

The data were primarily gathered through in-depth, semi-structured interviews during multiple sitevisits to Lenggong Valley. This aligns with the scope of this research, which requires a deeper understanding of local stakeholders and local authorities' perspectives about the characteristics of Lenggong local food. The interview protocol was also used to assist the researcher to obtain relevant information from the informant. The interview protocol is constructed based on the literature review and research question of the study. To further strengthen the finding of this study, participant observation was used. This is in line with Creswell (2003) who stated that observation can be an 
INTERNATIONAL JOURNAL OF ACADEMIC RESEARCH IN BUSINESS AND SOCIAL SCIENCES

Vol. 10, No. 6, June, 2020, E-ISSN: 2222-6990 @ 2020 HRMARS

effective method to complement other methods. Data were analyzed using the constant comparative method to establish codes and categories for the development of main themes to answer the research question of the study.

\section{Finding and Discussions}

Four main characteristics of Lenggong local food were identified through in-depth, semi-structured interviews and participant observation with the local stakeholders and authorities. The finding for Lenggong local food characteristics is discussed as follows

\section{a) Practicing food culture using natural ingredients}

The formation of local food recipes in Lenggong Valley is based on the abundance of natural resources. Previously, people lived predominantly in the rural area and had to utilize natural resources, including rivers and plants, to create unique recipes for their everyday foods. They were creative in creating recipes for survival which they shared among the community. Furthermore, the previous people in Lenggong Valley utilised bamboo as a cooking equipment to cook dishes like rice and fish.

"...rice cooked in bamboo, according to the history, before the existence of cooking pot, before the cooking pot is readily available, all the food were cooked in bamboo including the fish. In the old times there was no market like now, we sought everything from the river, from the lake, boiled it or we call it as asam rebus (sour soup), similar to asam pedas (hot sour gravy) ..." (Traditional local food expert 3)

"...in the old times we cannot easily find fresh vegetables from the market. The villagers previously lived beside the forest which meant any food that can be eaten were their only food, for example umbut, that is gathered from rattan tree or bayas (a type of palm tree) ..." (Traditional local food expert 5)

They also obtained the cooking skill of the previous generation by using wild edible plants. The experience in helping their family members search for food ingredients in the forest such as local herbs and spices, grow and harvest food at their backyard, and prepare and cook food for their family were highly valued as explained by most of the informants. Interestingly, this culinary tradition is still being practiced until today among the community in Lenggong Valley.

"...I remember my late father when he made and taught me how to prepare rattan pith, he took the soft tip of the rattan pith and roasted it using firewood. Then he peeled the skin and used only the inner part of the pith. He said that if he took the raw pith and then directly boiled it, the bitter taste would remain. That was the main reason why it has to be roasted. The bitter taste would be reduced, then the final taste would be creamy, sweet and slightly bitter, so it has become one of the traditional dishes that have been prepared for generations..." (Traditional local food expert 3)

"....in the forest we can have pucuk cemperai, pucuk salam... these are young shoots that can be eaten, but if the previous generation did not start eating it, how can local people in this generation eat pucuk cemperai and pucuk salam? Who showed it? The past generation..." (Traditional local food expert 4) 
INTERNATIONAL JOURNAL OF ACADEMIC RESEARCH IN BUSINESS AND SOCIAL SCIENCES Vol. 10, No. 6, June, 2020, E-ISSN: 2222-6990 @ 2020 HRMARS

\section{b) Malay traditional food as main dishes}

The majority of the local food in Lenggong Valley were based on the Malay cuisine due to a large number of Malay ethnic populations there. Furthermore, most Malay local people there had Pattani background which resulted from intermarriages and are thus known as "Malay-Pattani". Thus, some of Lenggong's dishes were influenced by the Pattani culture in Thailand. Even though local foods are dominated by the Malay-Pattani ethnic background, however, the food has been accepted and adapted by other ethnic groups that have lived and are living in this area.

“...the foods here are very unique, because I see there are significant numbers of Malay community here. Actually the foods refer to the whole community or race, Malays, Chinese and Indians, but here we can see that Malay food are more dominant because Malay is the largest community here and the food can be accepted by other races as well. They can eat it freely, thus, I see the uniqueness is based on the togetherness of the community itself and the entrepreneurs are still maintaining the traditional characters of the foods..." (Local authority 1 )

"...my customers are mostly from the locals, Malays, a number of Chinese and Indian. The Chinese like our food (Malays traditional food), the Chinese here in Lenggong have similar taste as Malays..." (Local food producer 6)

The intensive use of spices and coconut milk in their cooking portrayed the characteristics of the Malay food culture. These spices are used to enhance the taste and aroma of the food whereby coconut milk or locally called santan is used to add a unique and creamy sweet taste into the cuisine. In addition, Kerabu is the signature dish for the community in Lenggong Valley. Besides coconut milk, lemongrass and galangal are also added into kerabu. The use of these ingredients to produce dishes like kerabu defined the strong identity and practice of the Malay food culture in Lenggong Valley.

"...here we do not really use powder spices, we use traditional spices. We crush the spices, and the spices' seeds are being sangai (seared) and crushed, that is what we cook. We do not really use powder spices..." (Local food producer 6)

"...actually the influence of Malay culture can be seen from the cooking. We use a lot of creamy ingredients, the first example is coconut milk, it becomes kerabu. There is a lot of kerabu types, kerabu umbut bayas, kerabu umbut beka, kerabu umbut rotan. The fish also is made into kerabu. It means the food in here contains fat. They also add lemongrass and galangal, that is the Malay food tradition here..." (Traditional local food expert 1)

\section{c) Freshwater fish sources are used as signature Dishes}

This area is rich with freshwater fish resources (Figure 2). Loma (thynnichthys thynnoides) fish and tengalan (puntius wool) fish are the most popular types of freshwater fish that can be found in this area, especially from the Perak River. These freshwater fish are uniquely found in this area and have become signature products for this area.

“...we have plenty of rivers here, such as Sungai Perak, Sungai Temelong, Sungai Lenggong, Sungai Kuak... These rivers have a lot of fish, the famous tengalan fish, loma fish which cannot be found in 
INTERNATIONAL JOURNAL OF ACADEMIC RESEARCH IN BUSINESS AND SOCIAL SCIENCES Vol. 10, No. 6, June, 2020, E-ISSN: 2222-6990 @ 2020 HRMARS

other rivers except in Perak. Tengalan fish can be found elsewhere but it will be different. Most of the loma fish are in Hulu Perak district..." (Local food producer 7)
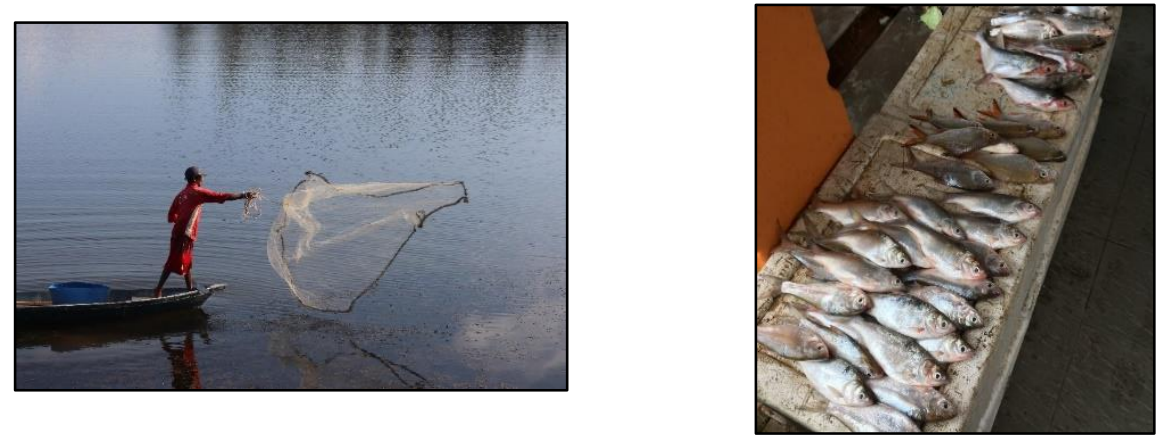

Figure 2. Freshwater fish sources in Lenggong Valley

Freshwater fish with carambola in coconut gravy is one of the famous traditional cuisines of Lenggong Valley. This cuisine contains freshwater fish like tengalan fish, unripe carambola, fresh coconut milk, bird eye chilies, fresh turmeric, lemongrass, shallot, shrimp paste, and seasoning. For some people, this cuisine is called masak lemak cili padi.

"...in my opinion, Lenggong is famous with its freshwater fish, its famous coconut gravy, baung fish in coconut gravy, tengalan fish in coconut gravy... The coconut gravy can be added with unripe carambola, bamboo shoots or cucumber. Other people called it lemak cili padi (spicy coconut gravy) ..." (Traditional local food expert 2)

Ikan masak pindang (savory steamed fish) is another popular traditional dish made from freshwater fish (Figure 3). This dish is wrapped with Ficus hispida leaf shoots or locally called senia leaf before it steamed for a long hour. The steaming process softens and crushes he fish bones making them fragile and easy to be consumed. The leaves also can be eaten as salad.

"...ikan masak pindang is a special fish dish here, it is not available at other places, it is special and unique, can be considered as Malay sardines, even the fish-bones can be eaten, the texture is soft as it is boiled for a long time, there is a place that produces ikan masak pindang at Lenggong, which is at Luat Village..." (Traditonal local food expert 4)
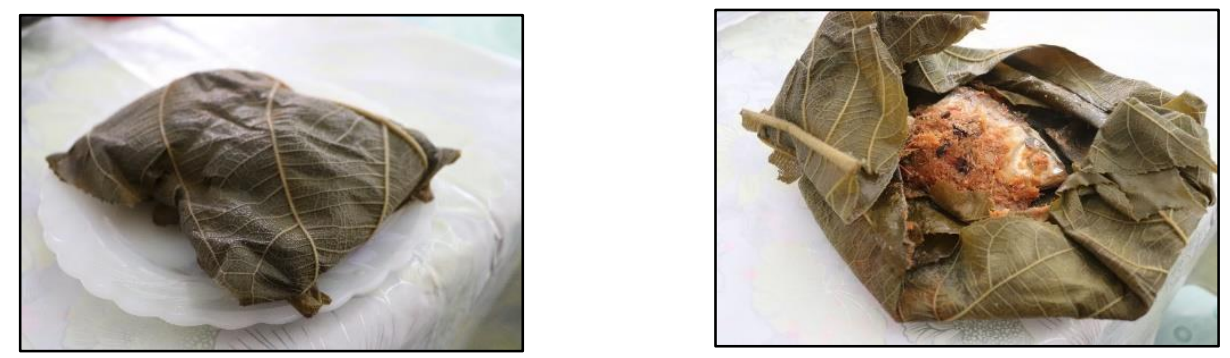

Figure 3. Ikan masak pindang, made from freshwater fish and senia leaves 
INTERNATIONAL JOURNAL OF ACADEMIC RESEARCH IN BUSINESS AND SOCIAL SCIENCES Vol. 10, No. 6, June, 2020, E-ISSN: 2222-6990 @ 2020 HRMARS

\section{d) The use of wild edible plants in traditional cooking}

Lenggong Valley is also rich with wild edible plants that are often used in the preparation of their daily dietary needs. Among them, umbut bayas or scientifically named as oncosperma horrida is commonly used among the locals in Lenggong Valley to make kerabu (traditional Malay salad) (Figure 4). The umbut bayas originated from the bayas tree (a type of wild palm tree). Umbut is located at the inner part of the palm tree (or known as heart of a plant), which looks like a white cylinder. To get the umbut, the palm tree needs to be cut down.

"...during the feast here we commonly serve kerabu umbut from the forest plants, for example umbut bayas (nibong palm shoot). Umbut bayas is still available. We work together to prepare the umbut bayas. Different regions serve it differently, for example there is umbut kelapa at Bagan Dato district. We cannot find umbut bayas there, the bayas (nibong palm) plant can only be obtained at Perak River valleys, at Hulu (upstream) Perak area, but it is not available at Hilir (downstream) Perak area, especially at Hulu Perak district..." (Local authority 2)
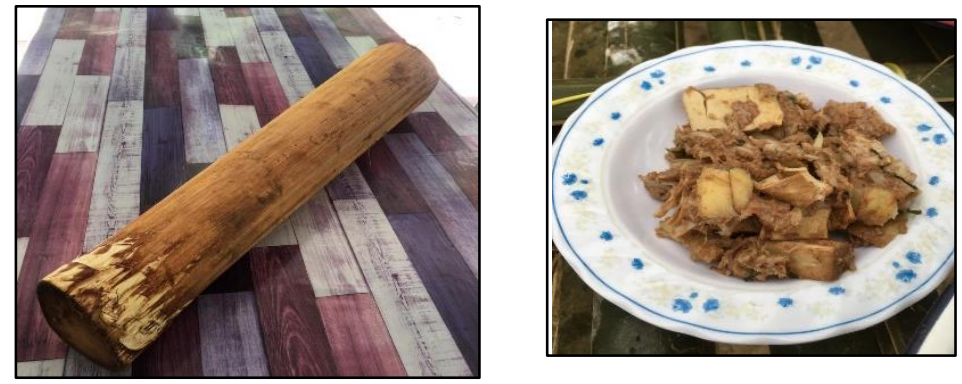

Figure 4. Umbut bayas used to prepare kerabu umbut bayas

Kemahang (Colacasia esculenta) is another edible wild plant that is popular among the community in Lenggong Valley (Figure 5). This native type of yam plant usually grows in the swamplands, marshlands, or sometimes in the wetlands. The people creatively incorporate this plant into a vegetable dish. It is usually cooked with coconut gravy and mixed with other ingredients such as prawns called gulai kemahang (kemahang yam in coconut gravy). Furthermore, it is believed that improper selection of the kemahang stem can cause itchiness when someone consumes it.

"...we cook kemahang coconut gravy using kemahang yam, a yam tree that can cause itchiness and typically found in the forest. If the cooking technique is wrong it will cause throat itchiness. Kemahang yam is not similar to the common yam..." (Local food producer 11)
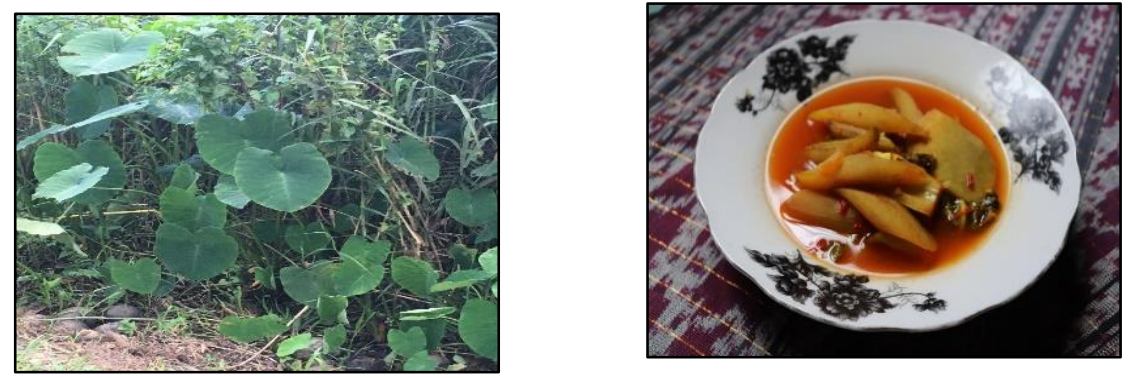

Figure 5. Kemahang, a type of wild edible plant use in preparing kemahang in coconut gravy 


\section{Conclusion and Implication}

This study has highlighted the characteristics of local food in Lenggong Valley, Perak. It showed that Lenggong Valley is rich with many natural resources such as freshwater fish, wild edible plants and diverse food cultural backgrounds. These natural resources are fully utilized to prepare many traditional cuisines that have been taught and shared by previous generations. The iconic dishes made from these food resources, for example, kerabu umbut bayas, rice cooked in bamboo, kemahang in coconut gravy, freshwater fish in coconut gravy with carambola and ikan masak pindang could be highlighted as signatures dishes that are linked to the locality of Lenggong Valley to present an image of the destination's culinary culture.

This valuable information is important to the state government, local authorities, and related agencies in integrating local food with existing tourism resource as a new attraction at Lenggong Valley. It also has potential to develop a more diverse tourism experience. The combination between diverse natural resources and the unique local food culture practiced by the local community in Lenggong Valley were found to be different from other regions, which is attractive and suitable to be incorporated in the marketing strategy to develop Lenggong as a potential food tourism destination in Malaysia. Furthermore, the findings can be used by the local food producers and homestay providers to offer authentic local food to the tourists that can reflect the identity and culinary image of Lenggong Valley. From here, it can increase the 'sense of place' of Lenggong Valley as a rural tourist destination in Malaysia.

\section{Limitation and Future Research}

This study explored the local food characteristics in Lenggong Valley. Future studies can investigate the strength and weaknesses of previous strategies to promote Lenggong local food and how it can be used to develop marketing strategies for food tourism development. Additionally, the interviews of this study mainly involved local stakeholders and local authorities. It is recommended that future studies involve the travellers who have visited and experienced the local food at Lenggong Valley to obtain a more comprehensive view.

\section{Acknowledgement}

The researchers would like to thank Universiti Putra Malaysia (UPM) for the financial support of this study (grant number: GP-IPS/2018/9620800).

\section{Corresponding author}

Mohd Nazri Abdul Raji, Faculty of Food Science and Technology, Universiti Putra Malaysia, 43400 UPM Serdang, Selangor, Malaysia. Email: mohdnazrihm775@gmail.com

\section{References}

Bessière, J. (1998). Local development and heritage: Traditional food and cuisine as tourist attractions in rural areas. Sociologia Ruralis, 38(1), 21-34.

Choe, J. Y., \& Kim, S. S. (2018). Effects of tourists' local food consumption value on attitude, food destination image, and behavioral intention. International Journal of Hospitality Management, 71, 1-10. doi:https://doi.org/10.1016/j.ijhm.2017.11.007

Creswell, J. W. (2003). Research design : Qualitative, quantitative and mixed method approaches (2nd ed.). Thousand Oaks: Sage Publications. 
INTERNATIONAL JOURNAL OF ACADEMIC RESEARCH IN BUSINESS AND SOCIAL SCIENCES Vol. 10, No. 6, June, 2020, E-ISSN: 2222-6990 @ 2020 HRMARS

Creswell, J. W. (2013). Qualitative inquiry and research design : Choosing among five approaches (3rd ed.). Thousand Oak: Sage Publication.

Du Rand, G. E., Heath, E., \& Alberts, N. (2003). The role of local and regional food in destination marketing. Journal of Travel \& Tourism Marketing, 14(3-4), 97-112. doi:10.1300/J073v14n03_06

Ellis, A., Park, E., \& Sangkyun, K. (2018). What is food tourism?. Tourism Management, 68, 250-263. doi:https://doi.org/10.1016/j.tourman.2018.03.025

Hassan, F., Zakaria, Z., Hamid, N. A., Rindam, M., \& Yahya, F. H. (2013). Peningkatan daya saing Lembah Lenggong berasaskan pelancongan sumber setempat. GEOGRAFIA Online Malaysian Journal of Society and Space, 9(2), 35-49.

Haven-Tang, C., \& Jones, E. (2005). Using local food and drink to differentiate tourism destinations through a sense of place. Journal of Culinary Science \& Technology, 4(4), 69-86. doi:10.1300/J385v04n04_07

Hjalager, A. M., \& Richard, G. (2003). Tourism and gastronomy. Routledge.

Horng, J. S., \& Tsai, C. T. (2012). Constructing indicators of culinary tourism strategy: An application of Resource-Based Theory. Journal of Travel \& Tourism Marketing, 29(8), 796-816. doi:10.1080/10548408.2012.730945

Jennings, G. (2001). Tourism research. Milton : John Wiley \& Sons .

Kim, S., \& Iwashita, C. (2015). Cooking identity and food tourism: The case of Japanese udon noodles. Tourism Recreation Research, 41(1), 89-100. doi:10.1080/02508281.2016.1111976

Kim, Y. G., Eves, A., \& Scarles, C. (2009). Building a model of local food consumption on trips and holidays: A grounded theory approach. International Journal of Hospitality Management, 28(3), 423-431. doi:https://doi.org/10.1016/j.ijhm.2008.11.005

Kwong, A. M., \& Mohamed, B. (2017). A review of Lenggong Valley as tourism destination from policy and organizational perspective. Journal of Tourism Research and Hospitality, 6(4), 1-12. doi:10.4172/2324-8807.1000196

Lebar, O. (2007). Penyelidikan kualitatif: Pengenalan kepada teori and metod. Tanjong Malim: Penerbit Universiti Pendidikan Sultan Idris.

Lenggong District Council. (2020). Offical Portal Lenggong District Council. Retrieved 2 January, 2020, from http://www.mdlg.gov.my/ms/mdlg/profil/latar-belakang

Lunchaprasith, T. (2017). Gastronomic experience as a community development driver: The study of Amphawa Floating Market as community-based culinary tourism destination. Asian Journal of Tourism Research, 2(2), 84-116.

Shobri, N. M., \& Hassan, K. (2017). Exploring the uniqueness of Lenggong, Perak in Malaysia. Multidisciplinary Academic Conference 2017. Kota Kinabalu, Sabah, Malaysia: SSR Scholars Group.

Silverman, D. (2013). Doing qualitative research (4th ed.). London: Sage Publication.

Sims, R. (2009). Food, place and authenticity: Local food and the sustainable tourism experience. Journal of sustainable tourism, 17(3), 321-336. doi:https://doi.org/10.1080/09669580802359293 